\title{
Physalis angulata L. (Solanaceae): a potential host-plant of stink bugs Edessa meditabunda F. (Hemiptera, Pentatomidae)
}

\author{
Diones Krinski ${ }^{1,2}$ \\ ${ }^{1}$ Programa de Pós-graduação em Zoologia, Departamento de Zoologia, Universidade Federal do \\ Paraná-UFPR, CP 19020, Jardim das Américas, CEP 81531-980, Curitiba, PR, Brazil \\ ${ }^{2}$ Corresponding author: Diones Krinski,diones.krinski@ufpr.br
}

KRINSKI, D. Physalis angulata L. (Solanaceae): a potential host-plant of stink bugs Edessa meditabunda F. (Hemiptera, Pentatomidae). Biota Neotrop. 13(2): http://www.biotaneotropica.org.br/v13n2/en/abstract?shortcommunication+bn02113022013

Abstract: Physalis angulata is native to South America. In Brazil is popularly known as camapú, balãozinho, juá-de-capote, bucho-de-rã, camambu, mata-fome, bate-testa and balão-rajado. Even being a species with wide ecological adaptation the studies on pest insects associated with these plants are incipient. Thus, this study reports for the first time the occurrence of stink bugs Edessa meditabunda on plants P. angulata in the Amazon region. Keywords: insect-pest, plant-reservoir, stink bug wing-black, Neotropical region.

KRINSKI, D. Physalis angulata L. (Solanaceae): uma potencial planta hospedeira de percevejos Edessa meditabunda F. (Hemiptera, Pentatomidae). Biota Neotrop. 13(2): http://www.biotaneotropica.org.br/v13n2/ pt/abstract?short-communication+bn02113022013

Resumo: Physalis angulata é nativa da América do Sul. No Brasil é popularmente conhecida como camapú, balãozinho, juá-de-capote, bucho-de-rã, camambu, mata-fome, bate-testa e balão-rajado. Mesmo sendo uma espécie com ampla adaptação ecológica, os estudos sobre a presença de possíveis insetos pragas associados a estas plantas são incipientes. Desta forma, este trabalho relata pela primeira vez a ocorrência de percevejos Edessa meditabunda em plantas de $P$. angulata na região amazônica.

Palavras-chave: inseto-praga, planta reservatório, percevejo asa-preta, região Neotropical. 


\section{Introduction}

The genus Physalis L. (Solanaceae) is originating from the Andes, with tropical cosmopolitan distribution, occurring from southern North America to South America, with centers of diversity in Mexico, United States and Central America (Fischer \& Martínez 1999, Silva \& Agra 2005). For Brazil, are recognized 11 species of Physalis (D'Arcy et al. 2005), with distribution in the various regions of the country, especially in the Amazon and the Northeast, where are found six species. The majority of species is wild, but some species are cultivated in countries such as Colombia, Mexico, China, Japan and recently in Brazil. These countries has as main consumer market the European countries, mainly of fresh fruits, because its fruits are used as food and also in pharmaceutical industry (Thomé \& Osaki 2010, Lorenzi and Matos 2002, Florez et al. 2000).

Physalis angulata (Linnaeus 1753) is native to South America and in Brazil is popularly known as camapú, balãozinho, juáde-capote, bucho-de-rã, camambu, mata-fome, bate-testa and balão-rajado (Muniz et al. 2011). Even being a species with wide ecological adaptation, information about their cultivation still is scarce (Muniz et al. 2011, Guimarães et al. 2010, Lima et al. 2006, Briguenti \& Madeira 2007). This characteristic is contrasting, mainly because $P$. angulata is a species widely used in popular medicine as anti-coagulant, anti-leukemic, anti-mutagenic, anti-inflammatory, anti-spasmodic, antiseptic, analgesic and treatment of diabetes, among others (Lin et al. 1992, Chiang et al. 1992) thus, was expected that more information about their cultivation were available.

Still, Lopes et al. (2006) report that researchs with several species of genus Physalis has increased considerably, reflecting its importance to the basic sciences such as Botany, Chemistry, Pharmacology, Toxicology and Genetics. However, studies on inscect pests associated with these plants are incipient (Maia et al. 2009). Therefore, knowledge and identification of species that may cause damage the culture of the cutleaf groundcherry are important to define efficient methods of control, since plants of $P$. angulata may be acting as a refuge for insects pest during the off-season. Thus, this study reports for the first time the occurrence of stink bugs Edessa meditabunda (Fabricius) (Hemiptera, Pentatomidae) in P. angulata plants in the Amazon region.

\section{Material and Methods}

Sampling of stink bugs E. meditabunda was conducted manually in plants of the cutleaf groundcherry ( $P$. angulata) between January and March 2012, on the farm Florentino, municipality of Novo

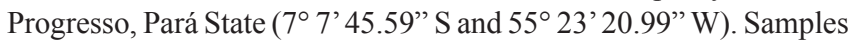
of stink bugs were made in plants located on the edges of rice and soybeans crops. To obtain the data, weekly ten plants were randomly selected, in which it was collected and recorded the quantities and sites of adults, nymphs, and egg masses of E. meditabunda.

\section{Results and Discussion}

A total of 848 adults, 325 nymphs and 41 egg masses ( 6 postures parasitized by microhymenopteran) of E. meditabunda was collected (Figure 1). It was observed that nymphs are associated with branches of $P$. angulata, while adults were observed on branches and fruits, and egg masses only in leaves, furthermore, the fluctuation of different developmental stages during sampling followed the same pattern (Figure 2). The mean values and standard error of adults, nymphs and egg masses found in each week's collection are presented in Table 1.

Although the cultivation of cutleaf groundcherry to be a newness in Brazil, there are reports of insects that cause damage to some species of Physalis, being that most of pest belonging to the order Hemiptera and Lepidoptera. However, the presence of E. meditabunda in Physalis plants only been recorded in Argentina for Physalis peruviana (Linnaeus 1763) (Bado et al. 2005). Other stink bugs are reported for $P$. peruviana, as Edessa rufomarginata (De Geer, 1773), Euschistus heros Fabricius 1974, Dichelops furcatus Fabricius 1775, Prepos sp., Orius sp., Dicyphus curcubitaeus (Spinola, 1852), Phithia picta (Drury, 1770), and Arvelius albopunctactus (De Geer, 1773), being that the last three were also recorded for Physalis ixocarpa Brot. ex Hornem., 1819 (Bado et al. 2005, Rufato et al. 2008, Silva et al. 2009).

According to Silva et al. (2009) the stink bugs E. rufomarginata and $P$. picta showed higher frequency of damage to crops $P$. peruviana in various regions of Rio Grande do Sul State, Brazil. The damage caused by E. rufomarginata occur due to sucking of sap made in the branches, causing yellowing and sometimes the thickening the stem, and necrosis of leaf tissue. In South America, some species of stink bugs feed on several plants important for the economy (Panizzi et al. 2000) and E. meditabunda is one of these pests, being recorded in various plants, including squash, chicory, lettuce, cotton, rice, potato, eggplant, beet, boldo, camapú (cape-gooseberry); chayote, citrus, pea, tobacco, sunflower, cassava, melon, pepper, chili , soybean, rattlepod and tomato (Costa \& Link 1974, Buzzi \& Miyazaki 1999, Lima \& Racca-Filho 1996, Lourenção et al. 1999, Panizzi 2002, Bado et al. 2005, Gonçalves et al. 2008, Golin et al. 2011, Krinski et al. 2012, Krinski \& Pelissari 2012, Krinski 2013), generally with reports of economic damage.

Considering, as reported by Lopes et al. (1974), the importance of knowledge of the host plants of a particular group of insects for studies of bio-ecology, population dynamics and predicting the appearance of new pests, and especially for its applicability in agriculture in general, data that report the occurrence stink bug E. meditabunda in plants of $P$. angulata are really relevant because this information
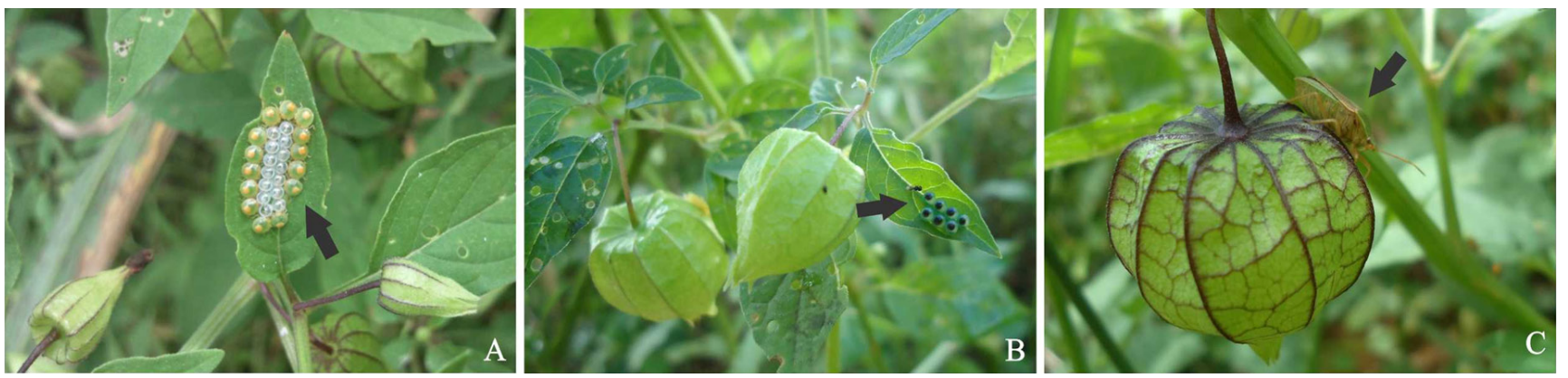

Figure 1. Edessa meditabunda in plants of Physalis angulata, Novo Progresso, Pará State, Brazil, January-March 2012. (A) egg shells surrounded by nymphs of first instars, (B) egg masses parasitized and one parasitoid (C) Adult on the cutleaf groundcherry fruit. 


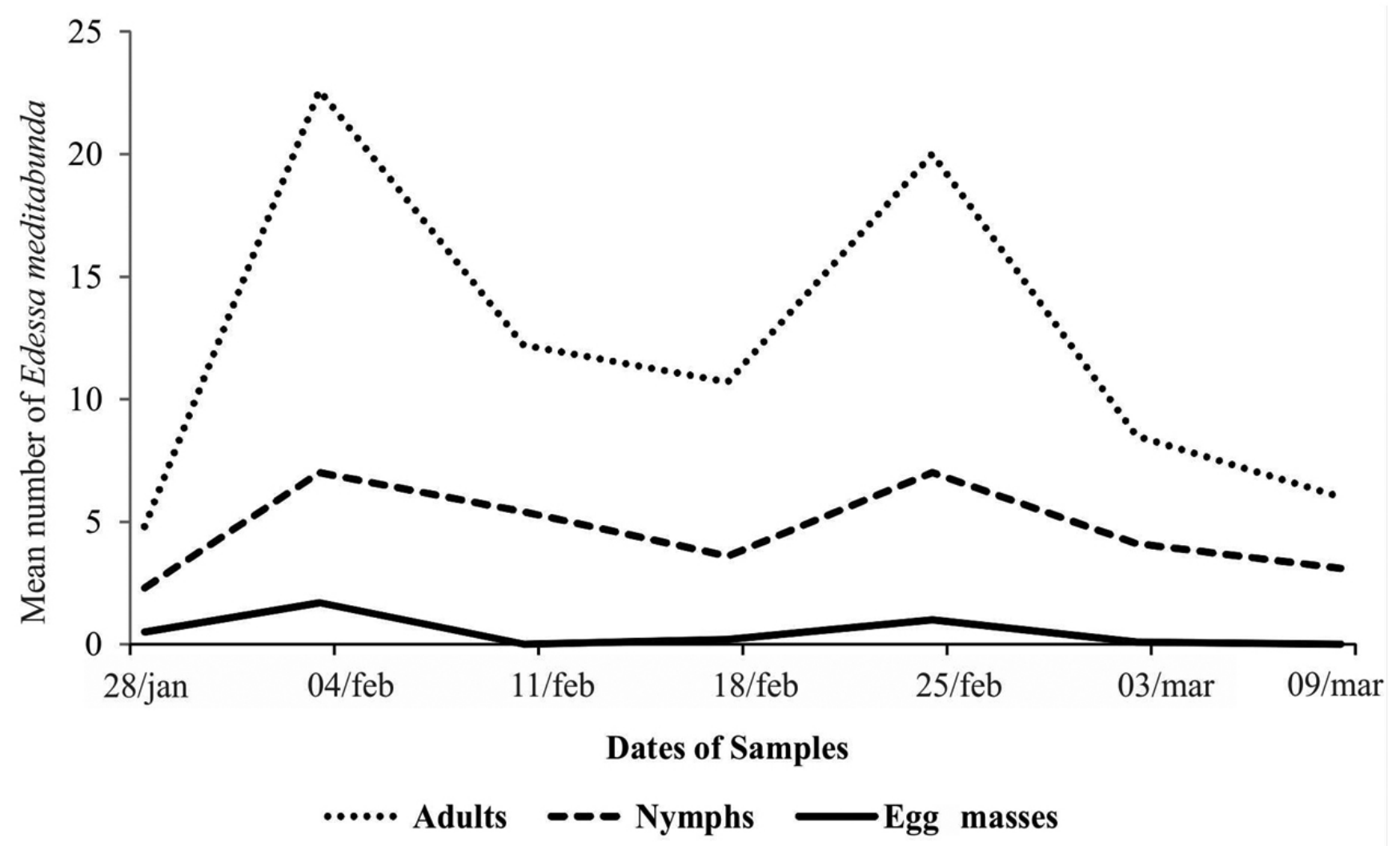

Figure 2. Fluctuation of adults, nymphs and egg masses of Edessa meditabunda found in Physalis angulata during the sampling period in Novo Progresso, Pará State, Brazil, January-March 2012.

Table 1. Total number and mean of adults, nymphs and egg masses of stink bugs Edessa meditabunda collected in Physalis angulata, Novo Progresso, Pará State, Brazil, January-March 2012.

\begin{tabular}{|c|c|c|c|c|c|c|c|}
\hline \multirow{3}{*}{ Stages } & \multicolumn{7}{|c|}{ Dates of samplings of stink bugs } \\
\hline & 28/jan/12 & $03 /$ feb/12 & 10/feb/12 & 17/feb/12 & $24 /$ feb/12 & $02 / \mathrm{mar} / 12$ & $09 / \mathrm{mar} / 12$ \\
\hline & $\begin{array}{c}\text { mean } \pm \mathrm{SE}^{1} \\
(\text { total })\end{array}$ & $\begin{array}{c}\text { mean } \pm \mathrm{SE} \\
\text { (total) }\end{array}$ & $\begin{array}{c}\text { mean } \pm \mathrm{SE} \\
\text { (total) }\end{array}$ & $\begin{array}{c}\begin{array}{c}\text { mean } \pm \mathrm{SE} \\
(\text { total })\end{array} \\
\end{array}$ & $\begin{array}{c}\text { mean } \pm \mathrm{SE} \\
\text { (total) }\end{array}$ & $\begin{array}{c}\begin{array}{c}\text { mean } \pm \mathrm{SE} \\
(\text { total })\end{array} \\
\end{array}$ & $\begin{array}{c}\text { mean } \pm \mathrm{SE} \\
(\text { total) }\end{array}$ \\
\hline Adults & $\begin{array}{l}4.8 \pm 0.44 \\
(48)\end{array}$ & $\begin{array}{c}22.6 \pm 5.47 \\
(226)\end{array}$ & $\begin{array}{c}12.2 \pm 1.97 \\
(122)\end{array}$ & $\begin{array}{c}10.7 \pm 1.25 \\
(107)\end{array}$ & $\begin{array}{c}20.00 \pm 5.18 \\
(200)\end{array}$ & $\begin{array}{c}8.50 \pm 1.76 \\
(85)\end{array}$ & $\begin{array}{c}6.00 \pm 2.61 \\
(60)\end{array}$ \\
\hline Nymphs & $\begin{array}{c}2.30 \pm 0.79 \\
(23)\end{array}$ & $\begin{array}{c}7.00 \pm 1.65 \\
(70)\end{array}$ & $\begin{array}{c}5.40 \pm 1.27 \\
(54)\end{array}$ & $\begin{array}{c}3.6 \pm 0.58 \\
(36)\end{array}$ & $\begin{array}{c}7.00 \pm 0.98 \\
(70)\end{array}$ & $\begin{array}{c}4.10 \pm 1.39 \\
(41)\end{array}$ & $\begin{array}{c}3.10 \pm 0.64 \\
(31)\end{array}$ \\
\hline $\begin{array}{l}\text { Egg } \\
\text { masses }\end{array}$ & $\begin{array}{c}0.50 \pm 0.27 \\
\text { (7) }\end{array}$ & $\begin{array}{c}1.7 \pm 0.86 \\
(17)\end{array}$ & $\begin{array}{c}0.00 \pm 0.00 \\
(0)\end{array}$ & $\begin{array}{c}0.20 \pm 0.13 \\
\text { (1) }\end{array}$ & $\begin{array}{c}1.00 \pm 0.45 \\
(13)\end{array}$ & $\begin{array}{c}0.10 \pm 0.10 \\
\text { (2) }\end{array}$ & $\begin{array}{c}0.00 \pm 0.00 \\
(0)\end{array}$ \\
\hline
\end{tabular}

can be used by producers who cultivate this species. The results of this paper are also important for farmers who grow other crops of agronomic interest, since $P$. angulata is presented as a host plant of stink bug $E$. meditabunda and can provide shelter for these insects during the off-season of various crops of economic interest.

Furthermore, because is common to find $P$. angulata in almost all Brazilian territory, often associated with crops, fruit orchards, gardens and vegetable gardens, this species has been considered as weed (Pittelkow et al. 2009). Then, due this characteristic of invasive plant, the knowledge of insects that occur in cutleaf groundcherry, such as E. meditabunda for example, may assist in pest management strategies, since $P$. angulata may be acting as a plant-reservoir of insects pests, especially when is considered plant cycle, which can pass the nine months (Lorenzi 2000, Braga 1976, Cruz et al. 2009, Freitas et al. 2002).

So, this record of E. meditabunda indicates that plants of $P$. angulata may represent an important site for breeding and feeding these stink bugs. Therefore, we suggest that additional studies on the biology, ecology and morphology of immature of E. meditabunda be realized in cutleaf groundcherry.

\section{Acknowledgements}

The author acknowledge the farmers of the Fazenda Florentino, Marlete Florentino, Eurides Florentino and Nadir de Lima Florentino (in memoriam) for allowing this research on their property. 


\section{References}

BADO, S.G., CERRI, A.M. \& VILELLA, F. 2005. Insectile fauna associated with two species of Physalis (Solanaceae) cultures in Argentine. Bol. San. Veg. Plagas 31(3):321-333.

BRAGA, R. 1976. Plantas do Nordeste, especialmente do Ceará. 3. ed. Escola Superior de Agricultura de Mossoró, Fortaleza, 540p. (Coleção Mossoroense, vol. 42).

BRIGUENTI, A.F. \& MADEIRA, C.M. 2007. Physalis. Uma alternativa para o fruticultor. J. Fruta XV 187.

BUZZI, Z.J. \& MIYAZAKI, R.D. 1999. Entomologia didática. 3. ed. Editora UFPR, Curitiba, 306p.

COSTA, C.E. \& LINK, D. 1974. Incidência de percevejos em soja. Rev. Centro Ciênc. Rurais. 4(4):397-400.

CHIANG, H.C., JAW, S.M. \& CHEN, C.F. 1992. Inhibitory effects of Physalin $\mathrm{B}$ and Physalin F on Various Human Leukemia Cells in vitro. Anticancer Res. 12(4):1155-1162. PMid:1503404.

CRUZ, D.L.S., RODRIGUES, G.S., DIAS, F.O., ALVES, J.M.A. \& ALBUQUERQUE, J.A.A. 2009. Weeds survey of rotational crops of soybean, corn, and irrigated rice in the savannah (cerrado) of Roraima. Rev. Agro@mbient. 3(1):58-63.

D'ARCY, W., ROJAS, C.B. \& NEE, M.H. 2005. Solanaceae. In Flora of the Venezuelan Guayana 9: 194-246 (P. Berry, B. Holst and K. Yatskievych, eds.). Missouri Botanical Garden Press, St. Louis.

FISCHER, G. \& MARTÍNEZ, O. 1999. Calidad y madurez de la uchuva (Physalis peruviana L.) em relación con la coloración del fruto. Agron. Colomb. 16(1-3):35-39.

FLOREZ, V.J., FISCHER, G. \& SORA, A.D. 2000. Produccion, poscosecha y exportación de la uchuva. UNIBIBLOS, Bogotá, 175p.

FREITAS, R.S., BERGER, P.G., FERREIRA, L.R., CARDOSO, A.A., FREITAS, T.A.S. \& PEREIRA, C.J. 2002. Weed Interference in Cotton Crop Under No-Tillage System. Plant. Daninha 20(2):197-205. http:// dx.doi.org/10.1590/S0100-83582002000200005

GOLIN, V., LOIÁCONO, M.S., MARGARÍA, C.B. \& AQUINO, D.A. 2011. Natural incidence of egg parasitoids of Edessa meditabunda (F.) (Hemiptera: Pentatomidae) on Crotalaria spectabilis in Campo Novo do Parecis, MT, Brazil. Neotrop. Entomol. 40(5):617-618. PMid:22068950.

GONÇALVES, L., ALMEIDA, F.S. \& MOTA, F.M. 2008. Effects of temperature on the development and reproduction of Edessa meditabunda (Fabricius, 1794) (Hemiptera: Pentatomidae). Acta Biol. Paranaense 37(12):111-121.

GUIMARÃES, E.T., LIMA, M.S., SANTOS, L.A., RIBEIRO, I.M., TOMASSINI, T.B.C., SANTOS, R.R., SANTOS, W.L.C. \& SOARES, M.B.M.B. 2010. Effects of seco-steroids purified from Physalis angulata L., Solanaceae, on the viability of Leishmania sp. Braz. J. Pharmacogn. 20(6):945-949.

KRINSKI, D. 2013. First report of phytophagous stink bug in chicory crop. Ciênc. Rural. 43(1):42-33. http://dx.doi.org/10.1590/S010384782012005000127

KRINSKI, D. \& PELISSARI, T.D. 2012. Occurrence of the stinkbug Edessa meditabunda F. (Pentatomidae) in differents cultivars of lettuce Lactuca sativa L. (Asteraceae). Biosci. J. 28(4):654-659.

KRINSKI, D., FAVETTI, B.M. \& BUTNARIU, A.R. 2012. First record of Edessa meditabunda (F.) on lettuce in Mato Grosso State, Brazil. Neotrop. Entomol. 41(1):79-80. http://dx.doi.org/10.1007/s13744-011-0012-x

LIMA, A.F. \& RACCA-FILHO, F. 1996. Manual de pragas e praguicidas: receituário agronômico. EDUR, Rio de Janeiro, 818p.
LIMA, C.R., COSTA-SILVA, J.H., LYRA, M.M.A., ARAÚJO, A.V., ARRUDA, V.M., DIMECH, G.S., EVÊNCIO, L.B., FRAGA, M.C.C.A., LAFAYETTE, S.S.L. \& WANDERLEY, A.G. 2006. Healing activity and pre-clinical toxicological study of phytotherapic sanativo ${ }^{\circledR}$. Acta Farm. Bonaer. 25(4):544-549.

LIN, Y.S., CHIANG, H.S., HONE, E., SHIN, S.J. \& WON, M.H. 1992. Immunomodulatory activity of various fractions derived from Physalis angulata L. extract. Am. J. Chin. Med. 20(3-4):233-243. PMid:1471607. http://dx.doi.org/10.1142/S0192415X92000242

LOPES, O.J., LINK, D. \& BASSO, I.V. Pentatomids of Santa Maria, RS - Preliminary listo f the host-plants. Rev. Centro Ciênc. Rurais, v. 4, p. 317-322, 1974.

LOPES, D.X.P., FREITAS, Z.M.F., SANTOS, E.P. \& TOMASSINI, T.C.B. 2006. Antimicrobial and phototoxic activities of Physalis angulata L (Solanaceae) extracts, fruits and roots. Braz. J. Pharmacogn. 16(2):206210.

LORENZI, H. \& MATOS, F.J.A. 2002. Plantas Medicinais no Brasil: nativas e exóticas cultivadas. Instituto Plantarum de Estudos da Flora, Nova Odessa, 512p.

LORENZI, H. 2000. Manual de identificação e controle de plantas daninhas: plantio direto e convencional. 5. ed. Plantarum, Nova Odessa, 339p.

LOURENÇÃO, A.L., PEREIRA, J.C.N.A., MIRANDA, M.A.C. \& AMBROSIANO, G.M.B. 1999. Damage Caused by Defoliators and Stink Bugs to Cultivars and Lines of Soybean of Two Maturity Groups. An. Soc. Entomol. Bras. 28(1):157-167. http://dx.doi.org/10.1590/S030180591999000100017

MAIA, V.C., ZART, M. \& BOTTON, M. 2009. Neolasioptera ramicola, a new species of Cecidomyiidae (Diptera) associated with Physalis angulata (Solanaceae). Rev. Bras. Entomol. 53(2):163-165. http://dx.doi. org/10.1590/S0085-56262009000200001

MUNIZ, J., KRETZSCHMAR, A.A., RUFATO, L., PELIZZA, T.R., MARCHI, T., DUARTE, A.E., LIMA, A.P.F. \& GARANHANI, F. 2011. Conduction systems for Physalis production in southern Brazil Rev. Bras. Frutic. 33(3):830-838. http://dx.doi.org/10.1590/S010029452011005000083

PANIZZI, A.R. 2002. Stink bugs on soybean in Northeastern Brazil and a new record on the southern green stink bug, Nezara viridula (L.) (Heteroptera: Pentatomidae). Neotrop. Entomol. 31(2):331-332. http:// dx.doi.org/10.1590/S1519-566X2002000200023

PANIZZI, A.R., McPHERSON, J.E., JAMES, D.G., JAVEHERY, M. \& McPHERSON, R.M. 2000. Stink bugs (Pentatomidae). In Heteroptera of economic importance (C.W. Schaefer and A.R. Panizzi, ed.). CRC, Boca Raton, p.432-434.

PITTELKOW, F.K., JAKELAITIS, A., CONUS, L.A., OLIVEIRA, A.A., GIL, J.A., ASSIS, F.C. \& BORCHARTT, L. 2009. Weed influence on transgenic soybean. Gl. Sci. Technol. 2(3):38-48.

RUFATO, L., RUFATO, A.R., SCHELEMPER, C., LIMA, C.S.M. \& KRETZSCHMAR, A.A.A. 2008. Aspectos técnicos da cultura da physalis. CAV/UDESC, Lages, UFPel, Pelotas, 100p.

SILVA, L.F., CONTREIRA, C.L., LIMA, C.S.M., BETEMPS, D.L. \& RUFATO, A.R. 2009. Principais pragas que afetam a cultura da physalis em Pelotas, Capão do Leão e Vacaria. In: Congresso Iniciação Científica. UFPEL, 4 p.

SILVA, K.N. \& AGRA, M.F. 2005. Comparative pharmacobotanical study on Nicandra physalodes and Physalis angulata (Solanaceae. Braz. J. Pharmacogn. 15(4):344-351.

THOMÉ, M. \& OSAKI, F. 2010. Nitrogen, phosphorus and potassium fertilization results on Physalis spp. yeld. Rev. Acad. Ciênc. Agrár. Ambient. 8(1):11-18. 